\title{
Rofecoxib did not slow progression of dementia in patients with established Alzheimer's disease
}

Reines SA, Block GA, Morris JC, et al. Rofecoxib: no effect on Alzheimer's disease in a 1-year, randomized, blinded, controlled study. Neurology 2004;62:66-71.

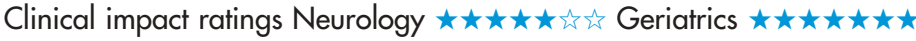

\section{In patients with established Alzheimer's disease (AD), does rofecoxib slow progression of dementia?}

\section{METHODS}

\begin{tabular}{|c|c|}
\hline & Design: randomised controlled trial. \\
\hline & Allocation: $\left\{\right.$ concealed $\left.{ }^{*}\right\} . \dagger$ \\
\hline एक & $\begin{array}{l}\text { Blinding: blinded \{patients, clinicians, data collectors, outcome } \\
\text { assessors, and data analysts\}t.* }\end{array}$ \\
\hline & Follow up period: 12 months. \\
\hline & Setting: 31 sites in the US. \\
\hline & $\begin{array}{l}\text { Patients: } 692 \text { patients who were } \geqslant 50 \text { years of age (mean age } \\
76 \text { y, } 53 \% \text { women), met standard research criteria for possible or } \\
\text { probable AD, had mild or moderate dementia (Mini-Mental State } \\
\text { Examination [MMSE] score } 14-26 \text { and a Clinical Dementia } \\
\text { Rating }[C D R] \text { global score no worse than moderate dementia), } \\
\text { and had a reliable informant or caregiver to accompany them to } \\
\text { clinic visits and ensure that they took the test medication. } \\
\text { Exclusion criteria: history of angina or congestive heart failure } \\
\text { with symptoms at rest; uncontrolled hypertension; myocardial } \\
\text { infarction, coronary artery bypass, angioplasty, or stent } \\
\text { replacement in the previous year; stroke, multiple lacunar } \\
\text { infarcts, or transient ischaemic events in the previous } 2 \text { years; } \\
\text { gastrointestinal bleeding in the previous } 3 \text { months; and long term } \\
\text { use of non-steroidal anti-inflammatory drugs ( } \geqslant 7 \mathrm{~d} / \mathrm{mo} \text { in the } \\
\text { previous } 2 \mathrm{mo} \text { ). }\end{array}$ \\
\hline & $\begin{array}{l}\text { Intervention: rofecoxib, } 25 \mathrm{mg} \text {, once daily ( } \mathrm{n}=346 \text { ) or placebo } \\
(\mathrm{n}=346 \text { ) for } 12 \text { months. }\end{array}$ \\
\hline $\begin{array}{ll}1 \\
2 \\
a_{6}\end{array}$ & $\begin{array}{l}\text { Outcomes: change in scores on the cognitive subscale of the AD } \\
\text { Assessment Scale (ADAS-cog) and the Clinician's Interview } \\
\text { Based Impression of Change with caregiver input (CIBIC+). }\end{array}$ \\
\hline$\stackrel{\longrightarrow}{\longrightarrow}$ & $\begin{array}{l}\text { Patient follow up: } 648 \text { patients }(94 \% \text { ) were included in the } \\
\text { intention to treat analysis (ie, patients with baseline data and } \geqslant 1 \\
\text { post-randomisation measure up to } 12 \text { months). }\end{array}$ \\
\hline & $\begin{array}{l}\text { *See glossary. } \\
\text { tInformation provided by author. }\end{array}$ \\
\hline
\end{tabular}

\section{MAIN RESULTS}

Patients in the rofecoxib and placebo groups did not differ for mean change in ADAS-cog and CIBIC+ scores from baseline to 12 months (table).

\section{CONCLUSION}

In patients with established Alzheimer's disease, 12 months of rofecoxib did not slow the progression of dementia compared with placebo.

For correspondence: Dr C Lines, Merck Research Laboratories, Blue Bell, PA USA. Chris_lines@merck.com

Source of funding: Merck Research Laboratories.
Rofecoxib $v$ placebo in patients with Alzheimer's disease*

\begin{tabular}{|c|c|c|c|}
\hline $\begin{array}{l}\text { Outcomes (mean } \\
\text { change from baseline } \\
\text { to } 12 \mathrm{mo} \text { ) }\end{array}$ & Rofecoxib & Placebo & Mean difference $(95 \% \mathrm{Cl})$ \\
\hline $\begin{array}{l}\text { ADAS-cog } \dagger \\
C|B| C+\ddagger\end{array}$ & $\begin{array}{l}4.84 \\
0.90\end{array}$ & $\begin{array}{l}5.44 \\
0.87\end{array}$ & $\begin{array}{r}-0.60(-1.90 \text { to } 0.70) \\
0.03(-0.12 \text { to } 0.18)\end{array}$ \\
\hline
\end{tabular}

*Higher change scores indicate greater declines regardless of sign. TADAS-cog $=$ AD Assessment Scale - cognitive subscale. Total scores range from $0-70$ errors.

$\ddagger C|B| C+=$ Clinician's Interview Based Impression of Change with caregiver input, a 7 point scale ranging from $1=$ very much improved to $7=$ very much worse. Reported values are change from a default score of 4 at baseline (no change); increase of approximately 1 point corresponds to "minimal worsening."

\section{Commentary}

hould patients with $A D$ be treated with non-steroidal antiinflammatory drugs (NSAIDS)? The study by Reines et al adds to the evidence suggesting that selective cyclooxygenase (COX)-2 inhibition with rofecoxib does not modify the course of mild to moderate $A D$, at least over a 12 month period. Similar negative results were found in a previous randomised trial comparing rofecoxib, naproxen, and placebo, which suggests that non-selective NSAIDS also do not slow cognitive decline. Although most adverse events were not severe, gastrointestinal adverse effects were higher in the treatment groups than in the placebo groups. These negative trials occurred despite compelling animal data that neuroinflammation might contribute to the pathophysiology of $A D$ and epidemiological data that NSAIDs might modify the course of clinical progression.

This study will not be the last we hear of anti-inflammatory drugs for $A D$. Longer duration trials ( $\geqslant 2$ years) may be required to show meaningful benefits, although this seems unlikely. Different patient groups need further attention, specifically patients with severe dementia and those at risk of dementia. Large trials are under way to see whether prophylactic NSAID or COX-2 treatment in at risk elderly patients will alter the incidence of $A D$.

In the absence of clear benefits, however, a treatment with greater risk of adverse effects (including increased admissions for heart failure ${ }^{2}$ ) and cost cannot be justified. Until further studies are available, there is no evidence to support the routine use of NSAIDs in the treatment or prevention of $A D$.

Garrett Riggs, MD, PhD Robert Holloway, MD, MPH University of Rochester Medical Center Rochester, New York, USA

1 Aisen PS, Schafer KA, Grundman M, et al. Effects of rofecoxib or naproxen vs placebo on Alzheimer disease progression: a randomized controlled trial. JAMA 2003;289:2819-26.

2 Mamdani M, Juurlink DN, Lee DS, et al. Cyclo-oxygenase-2 inhibitors versus non-selective non-steroidal anti-inflammatory drugs and congestive heart failure outcomes in elderly patients: a population-based cohort study. Lancet 2004;363:1751-6. 